Utah State University

DigitalCommons@USU

Reports

Publications

$4-2010$

\title{
The Sagebrush Steppe Treatment Evaluation Project (SageSTEP): A Test of State-and-Transition Theory
}

James Mclver

Oregon State University

Mark W. Brunson

Utah State University, mark.brunson@usu.edu

Steve Bunting

University of Idaho

Jeanne C. Chambers

USDA Forest Service

Nora Devoe

USDI Bureau of Land Management

Paul Doescher

Oregon State University

Seellowext thisand fadditionahworks,at: https://digitalcommons.usu.edu/sagestep_reports

Part of the Plant Sciences Commons

\section{Recommended Citation}

Mclver, J.D.; Brunson, M.; Bunting, S.C., and others. 2010. The Sagebrush Steppe Treatment Evaluation Project (SageSTEP): a test of state-and-transition theory. Gen. Tech. Rep. RMRS-GTR-237. Fort Collins, CO: U.S. Department of Agriculture, Forest Service, Rocky Mountain Research Station. 16 p.

This Report is brought to you for free and open access by the Publications at DigitalCommons@USU. It has been accepted for inclusion in Reports by an authorized administrator of DigitalCommons@USU. For more information, please contact digitalcommons@usu.edu.

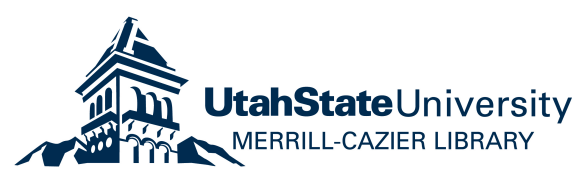




\section{Authors}

James Mclver, Mark W. Brunson, Steve Bunting, Jeanne C. Chambers, Nora Devoe, Paul Doescher, James Grace, Dale Johnson, Steve Knick, Richard F. Miller, Mike Pellant, Fred Pierson, David Pyke, Kim Rollins,

Bruce Roundy, Eugene W. Schupp, Robin Tausch, and David Turner 
USDA

United States

Department

of Agriculture

Forest Service

Rocky Mountain

Research Station

General Technical Report

RMRS-GTR-237

April 2010

[445)

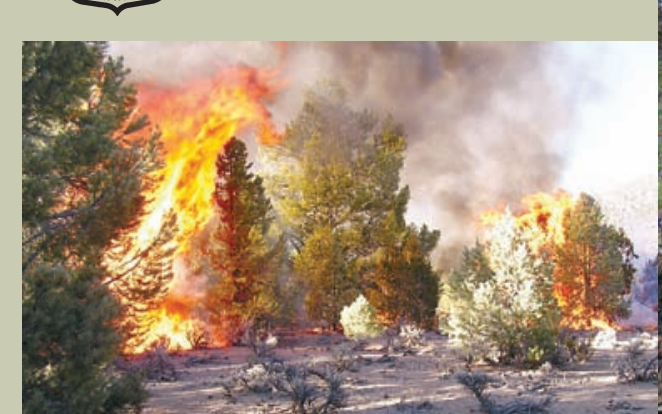

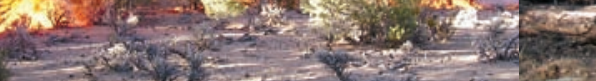

\section{Year after burn Blue Mountain}

Prescribed fire $\rightarrow$ Seven Mile $I$
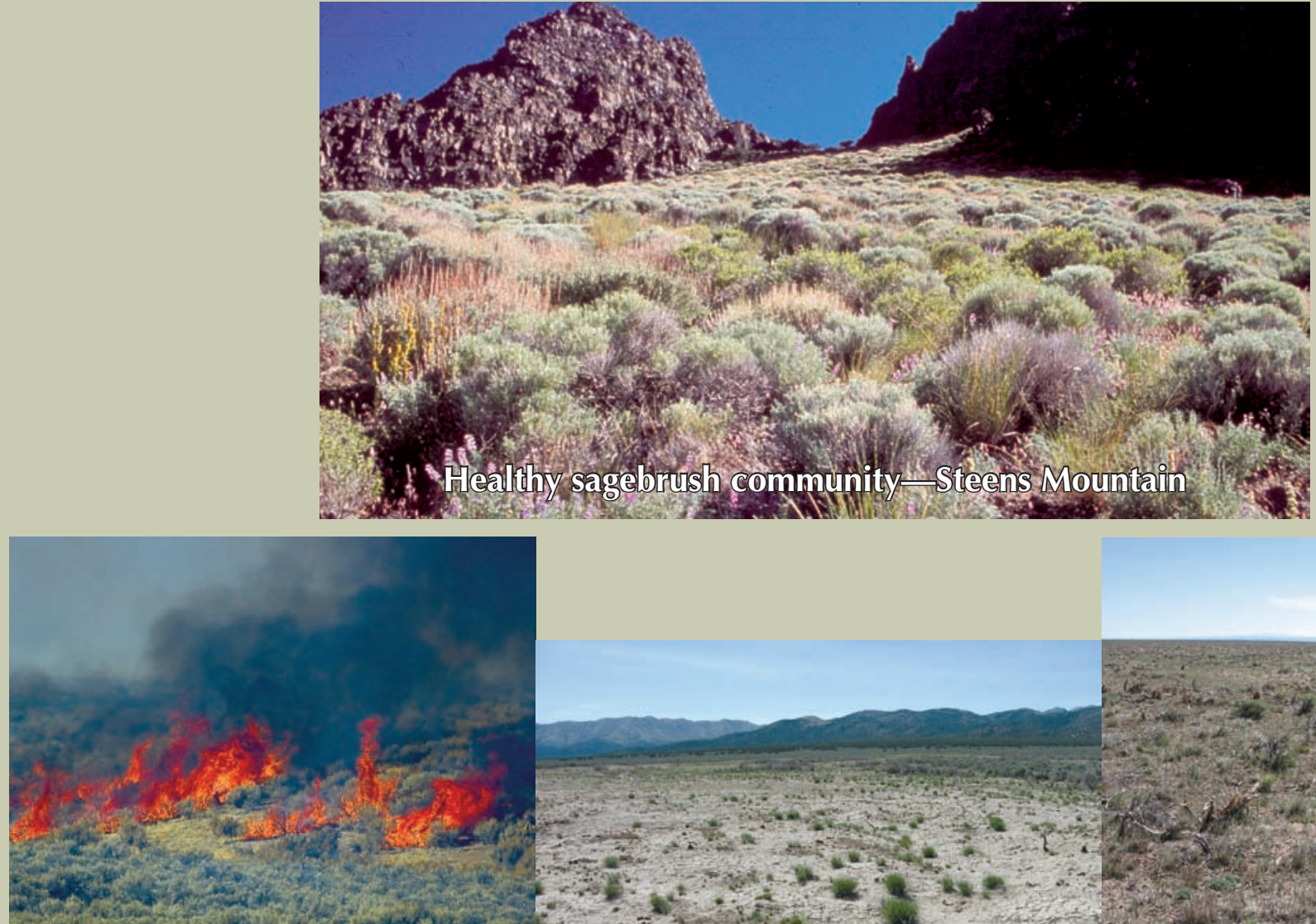

Prescribed fire - Owyhee

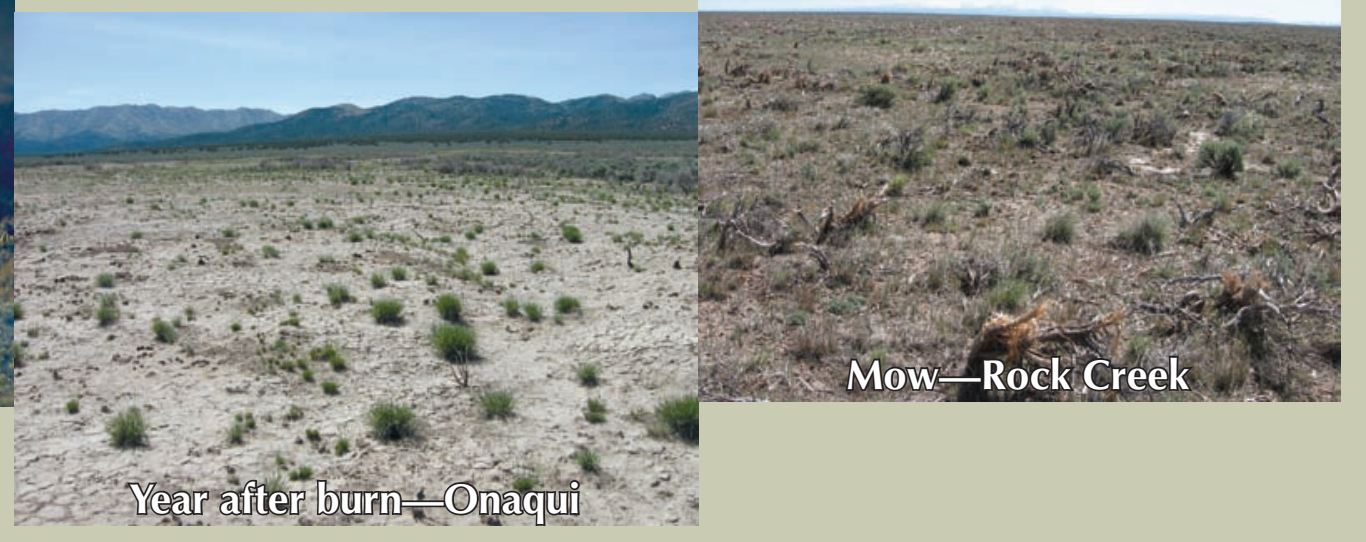


Mclver, J.D.; Brunson, M.; Bunting, S.C., and others. 2010. The Sagebrush Steppe Treatment Evaluation Project (SageSTEP): a test of state-andtransition theory. Gen. Tech. Rep. RMRS-GTR-237. Fort Collins, CO: U.S. Department of Agriculture, Forest Service, Rocky Mountain Research Station. 16 p.

\section{Abstract}

The Sagebrush Steppe Treatment Evaluation Project (SageSTEP) is a comprehensive, integrated, long-term study that evaluates the ecological effects of fire and fire surrogate treatments designed to reduce fuel and to restore sagebrush (Artemisia spp.) communities of the Great Basin and surrounding areas. SageSTEP has several features that make it ideal for testing hypotheses from state-and-transition theory: it is long-term, experimental, multisite, and multivariate, and treatments are applied across condition gradients, allowing for potential identification of biotic thresholds. The project will determine the conditions under which sagebrush steppe ecological communities recover on their own following fuel treatment versus the communities crossing ecological thresholds, which requires expensive active restoration.

Keywords: fire surrogates, fire regimes, thresholds, resilience
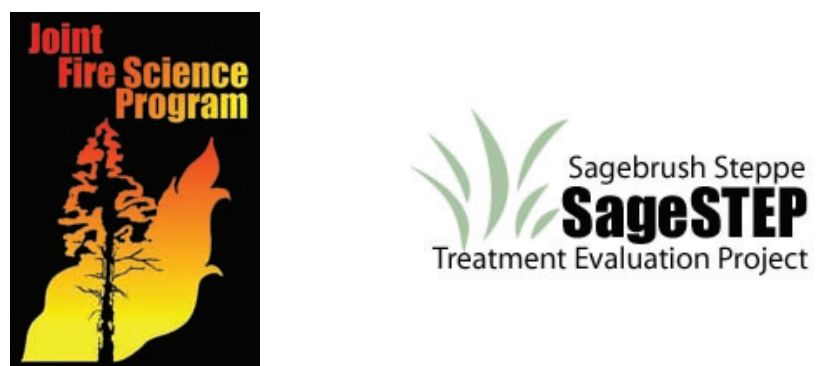

You may order additional copies of this publication by sending your mailing information in label form through one of the following media. Please specify the publication title and series number.

Fort Collins Service Center

$\begin{aligned} \text { Telephone } & (970) \text { 498-1392 } \\ \text { FAX } & (970) \text { 498-1122 } \\ \text { E-mail } & \text { rschneider@fs.fed.us } \\ \text { Web site } & \text { http://www.fs.fed.us/rm/publications } \\ \text { Mailing address } & \text { Publications Distribution } \\ & \text { Rocky Mountain Research Station } \\ & \text { 240 West Prospect Road } \\ & \text { Fort Collins, CO 80526 }\end{aligned}$

Rocky Mountain Research Station

240 W. Prospect Road

Fort Collins, Colorado 80526 


\section{Authors}

James Mclver is a Senior Research Associate Professor with the Eastern Oregon Agricultural Research Station at Oregon State University in Union, OR.

Mark Brunson is a Professor with the Department of Environment and Society at Utah State University in Logan, UT.

Steve Bunting is a Professor with the Department of Rangeland Ecology and Management at University of Idaho in Moscow, ID.

Jeanne Chambers is a Research Ecologist with the USDA Forest Service, Rocky Mountain Research Station, in Reno, NV.

Nora Devoe is Research Coordinator for Nevada with the USDI Bureau of Land Management in Reno, NV.

Paul Doescher is a Professor with the Department of Forest Resources at Oregon State University in Corvallis, OR.

James Grace is a Senior Research Ecologist with the USGS National Wetlands Research Center in Lafayette, LA.

Dale Johnson is a Professor with the Department of Environmental and Resource Sciences at University of Nevada in Reno, NV.

Steve Knick is a Wildlife Ecologist with the USGS Forest and Rangeland Ecosystems Science Center in Boise, ID.

Richard Miller is a Range Ecologist with the Department of Rangeland Ecology and Management at Oregon State University in Corvallis, OR.

Mike Pellant is a Range Management Specialist with the USDI Bureau of Land Management in Boise, ID.

Fred Pierson is a Research Hydrologist with the Northwest Watershed Research Center, Agricultural Research Services, in Boise, ID.

David Pyke is a Research Ecologist with the USGS Forest and Rangeland Ecosystems Science Center in Corvallis, OR.

Kim Rollins is an Associate Professor with the Department of Applied Economics and Statistics at University of Nevada in Reno, NV.

Bruce Roundy is a Professor with the Department of Plant and Wildlife Sciences at Brigham Young University in Provo, UT.

Eugene Schupp is a Professor with the Department of Wildland Resources at Utah State University in Logan, UT.

Robin Tausch is a Research Ecologist with the USDA Forest Service, Rocky Mountain Research Station, in Reno, NV.

David Turner is a Statistician with the USDA Forest Service, Rocky Mountain Research Station, in Logan, UT. 
Contents

Introduction 1

State-and-Transition Models (SIMs) 2 STMs for Sagebrush Steppe Systems. 2 SageSTEP DESIGN and SIMs 6

Treatment Plot 8

Site Distribution. 8

Treatments

11

Measured Variables

12

Analyses

13

Human Aspects

13

Sociopolitical

13

Economic

14

Outreach

14

Summary

14

Acknowledgments

15

References

15

ii 


\section{The Sagebrush Steppe Treatment Evaluation Project (SageSTEP): A Test of State-and-Transition Theory}

\section{Introduction}

Sagebrush (Artemisia spp.) habitats occupy 40 million ha in the western United States and Canada (Knick and others 2003). Home to more than 350 vertebrate species (Wisdom and others 2002), sagebrush steppe lands represent an important recreation area, are the primary forage base for the western rangeland livestock industry, and provide water in a semi-arid region with one of the fastest growing human populations in North America. Sagebrush ecosystems are considered to be among the most endangered in western North America (Noss and others 1995; Bunting and others 2002), with perhaps a third of the pre-settlement area of sagebrush already converted to other land uses or highly degraded. Over the past 100 years, fire suppression, inappropriate livestock grazing, expansion of native conifers like juniper and pinyon pine (Juniperus occidentalis, J. osteosperma; Pinus monophylla, P. edulis), and invasion of exotic weeds such as cheatgrass (Bromus tectorum) have contributed most to the decline of sagebrush communities in the Intermountain Region (Pellant 1994; Miller and Tausch 2001). In more mesic locations, conifer expansion and depletion of fine fuels due to inappropriate livestock grazing has shifted fire regimes from relatively frequent and low to mixed severity (10 to 50 years mean fire return interval) to more infrequent and high severity ( $>50$ years mean fire interval) (Miller and Rose 1999; Miller and Tausch 2001; Miller and Heyerdahl 2008). In some places, this shift has resulted in nearly a six-fold increase in fuel loads (from 7 to 40 tons/ha) (Tausch and others 2004). In more xeric sagebrush ecosystems, exotic annual grasses have become more dominant at the expense of native perennial species, and these annuals have shifted mean fire return intervals from $>50$ years to $<10$ years in some places (Whisenant 1990). Under current climatic conditions, both pinyon and juniper woodlands and exotic annual grasses have the potential to dominate an even greater area (Betancourt 1987; West and Van Pelt 1987; Miller and others 2000; Wisdom and others 2002), and global warming is likely to exacerbate this trend (Tausch and Nowak 2000; Pyke and Knick 2003; Neilson and others 2005). Millions of taxpayer dollars are spent annually for fire suppression as a result of increased fire risk and sagebrush steppe degredation. The cumulative effects of degrading sagebrush habitats include increased threat to property and life, higher erosion and sedimentation, decreased water quality, declines in the forage base for domestic livestock, and decreased habitat for big game and threatened wildlife species (Knick and others 2003).

Federal land managers are attempting to arrest the conversion of sagebrush steppe communities into woodland and cheatgrass, restore a desirable herbaceous understory, and reduce fuel loads by applying treatments such as prescribed fire, mowing, chaining, cutting, masticating, and/or herbicides. Although site-specific information exists on the effectiveness of some treatments, there is scant multidisciplinary scientific information available on treatment outcomes over the range of environmental and ecological conditions that occur across sagebrush habitats. Further, little is known about the actual costs of these treatments, particularly relative to fire suppression efforts, or how acceptable they are to society for reducing fuels and restoring more desirable ecological conditions. Managers need multidisciplinary scientific information on the recovery potential of sagebrush ecosystems exhibiting different degrees of degradation and on the effectiveness of available treatments. Increasingly, managers rely on state-and-transition models (STMs) to determine recovery potentials and treatment alternatives for shrubland and grassland ecosystems (Briske and others 2005, 2006). In sagebrush ecosystems, the multisite, multidisciplinary scientific data necessary to 
evaluate the existing states and transitions and to develop appropriate prescriptions are lacking.

The Sagebrush Steppe Treatment Evaluation Project (SageSTEP) is a unique and unprecedented effort designed to collect these data and fully develop STMs for managing sagebrush steppe lands in the Interior West. SageSTEP tests specific predictions from STMs experimentally by evaluating the ecological effects of prescribed fire and its surrogates (mechanical and herbicide treatments) at 21 sagebrush steppe sites in the Great Basin and surrounding areas. The project also evaluates social acceptability of fire and fire surrogate treatments, measures costs and benefits of treatment application, and explores ways to place information in the hands of land managers. In this report, we briefly introduce the concept and value of state-and-transition modeling for management and research, present STMs that represent the two ecological experiments within SageSTEP, and describe the research design in the context of those STMs. We then describe the human aspects of SageSTEP research, including its sociopolitical, economic, and outreach components.

\section{State-and-Transition Models (STMs)}

With his observation that ecosystems could develop alternate stable states at different times on the same piece of ground, Holling (1973) set the stage for current thinking in rangeland ecology and its focus on threshold dynamics and STMs. Since their introduction about 20 years ago (Westoby and others 1989; Laycock 1991), STMs have become increasingly popular for vegetation evaluation and rangeland management in the western United States (Briske and others 2005; Bestelmeyer 2006). In contrast to traditional "range models" (Dyksterhuis 1949), STMs recognize and accommodate multiple successional pathways on single sites. Some pathways lead to alternate community phases within a single stable state, and the ecosystem can move among these phases without changing state. Other pathways may result in threshold crossings to alternative stable states. Once a threshold is crossed, the ecosystem typically does not return to its previous state without active management (Briske and others 2006). Rangeland professionals are knowledgeable enough to link soil and vegetation characteristics with STMs and, in fact, these are essential elements of Ecological Site Descriptions (Pyke and others 2002; Bestelmeyer and others 2004).
Developing STMs for managed landscapes is important for both management and research. Coupled with information from ecological site descriptions, STMs enhance managers' abilities to predict treatment effects and outcomes and to determine what risks they might take if they decide to do nothing (Briske and others 2006). From a research perspective, the construction of STMs encourages ecologists to think clearly about ecosystem structure and ecological processes and the influence of human and natural disturbances, species invasions, and management actions. STMs can be used both to identify relevant management hypotheses (Briske and others 2005) and to design experiments to test them. SageSTEP is a management experiment that is specifically designed to test hypotheses related to STMs and threshold crossings in sagebrush steppe ecosystems.

\section{STMs for Sagebrush Steppe Systems}

SageSTEP consists of two similarly designed experiments. The woodland experiment focuses on pinyon and/or juniper expansion into more mesic sagebrush steppe sites (12 to 14 inches precipitation), and the sage/cheat experiment focuses on cheatgrass invasion into more xeric sites (10 to 12 inches precipitation). We present a standard STM for each experiment, but we recognize that details of treatment response will vary among sites due to differences in vegetation composition and abundance, soils, elevation, aspect, slope, and climate (Tables 1 and 2). In addition, inherent site differences will likely influence the timing and trajectory of vegetation recovery. Thus, it is important to evaluate treatment responses for at least 10 years after treatment to capture the pattern and timing of recovery and to develop accurate STMs for each site.

For the woodland experiment, the sagebrush steppe reference state can be represented by three phases (Figure 1). Phase Ia depicts an herbaceous plant community consisting primarily of annual and perennial grasses and forbs that can persist on a site indefinitely with proper grazing and periodic low-intensity fire. If fire is suppressed and/or inappropriate grazing occurs, perennial herbaceous species decrease, sagebrush and other woody shrubs increase, and the site moves to Phase $\mathrm{Ib}$. Pinyon and juniper seedling recruitment is facilitated by sagebrush and other woody shrubs (Chambers and others 1999; Chambers 2000), and after an increase in shrubs, trees are able to establish and begin to increase their dominance on the site 


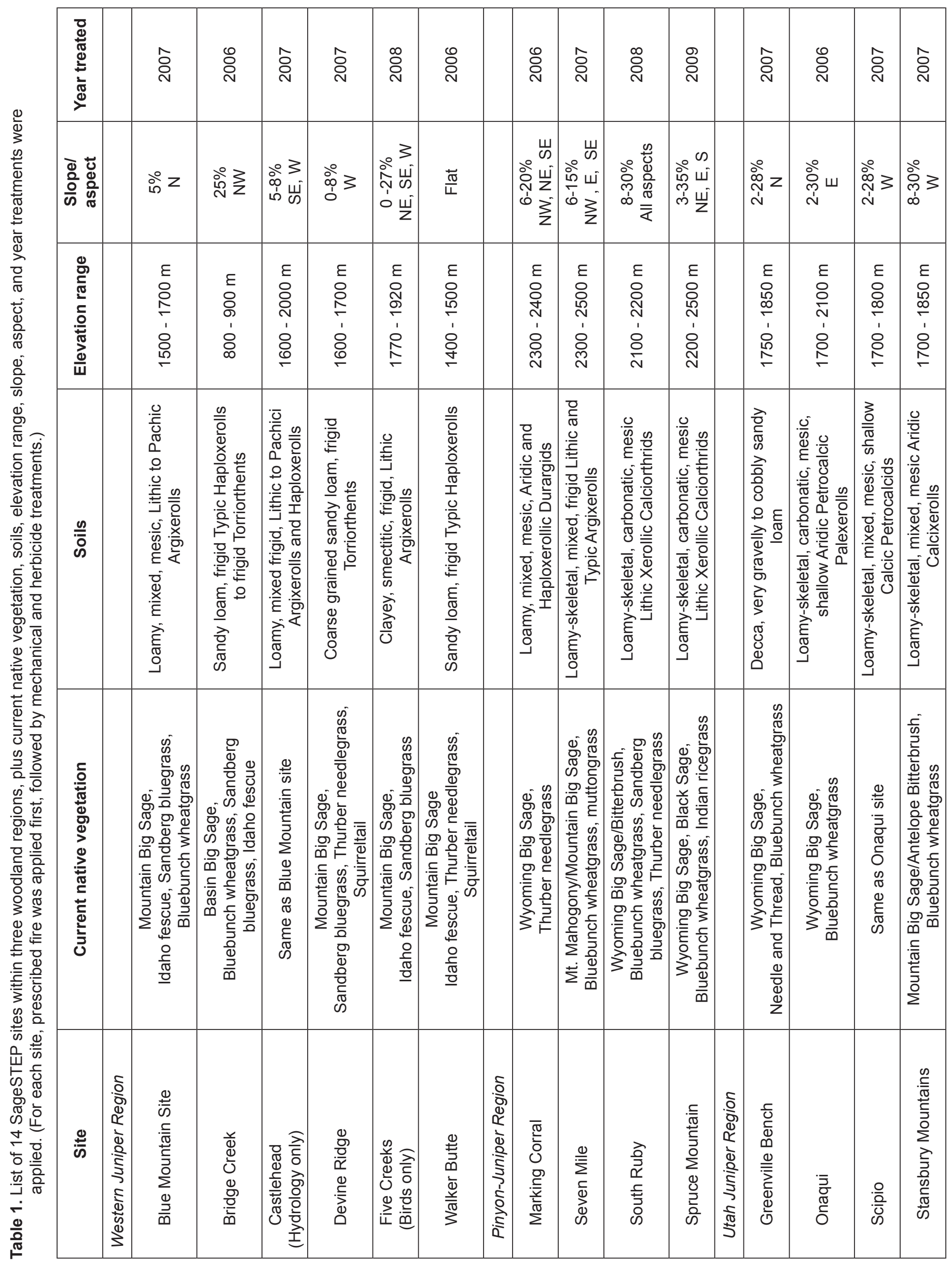




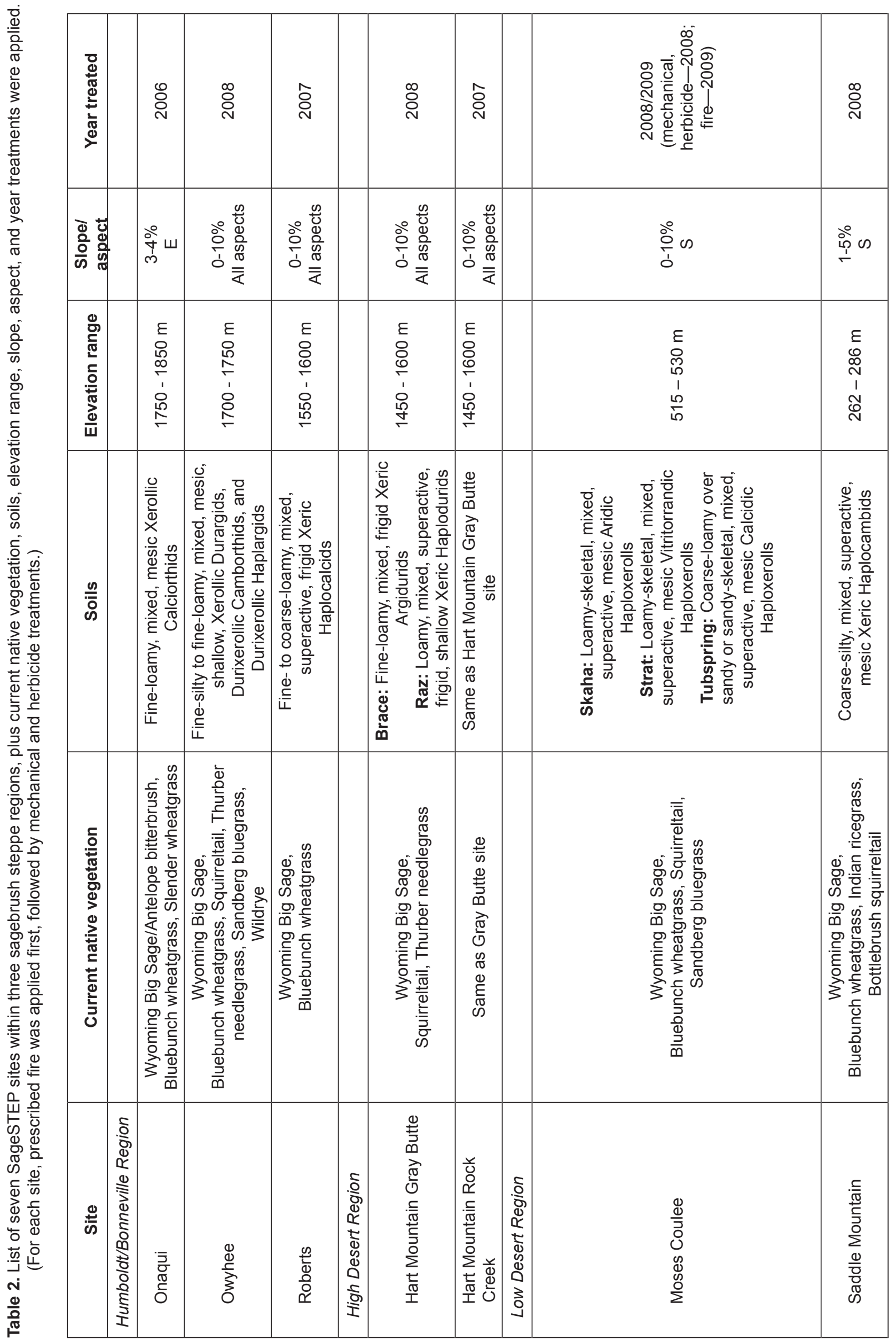




\section{WOODLAND \\ Sagebrush Steppe \\ State-and-Transition Model}

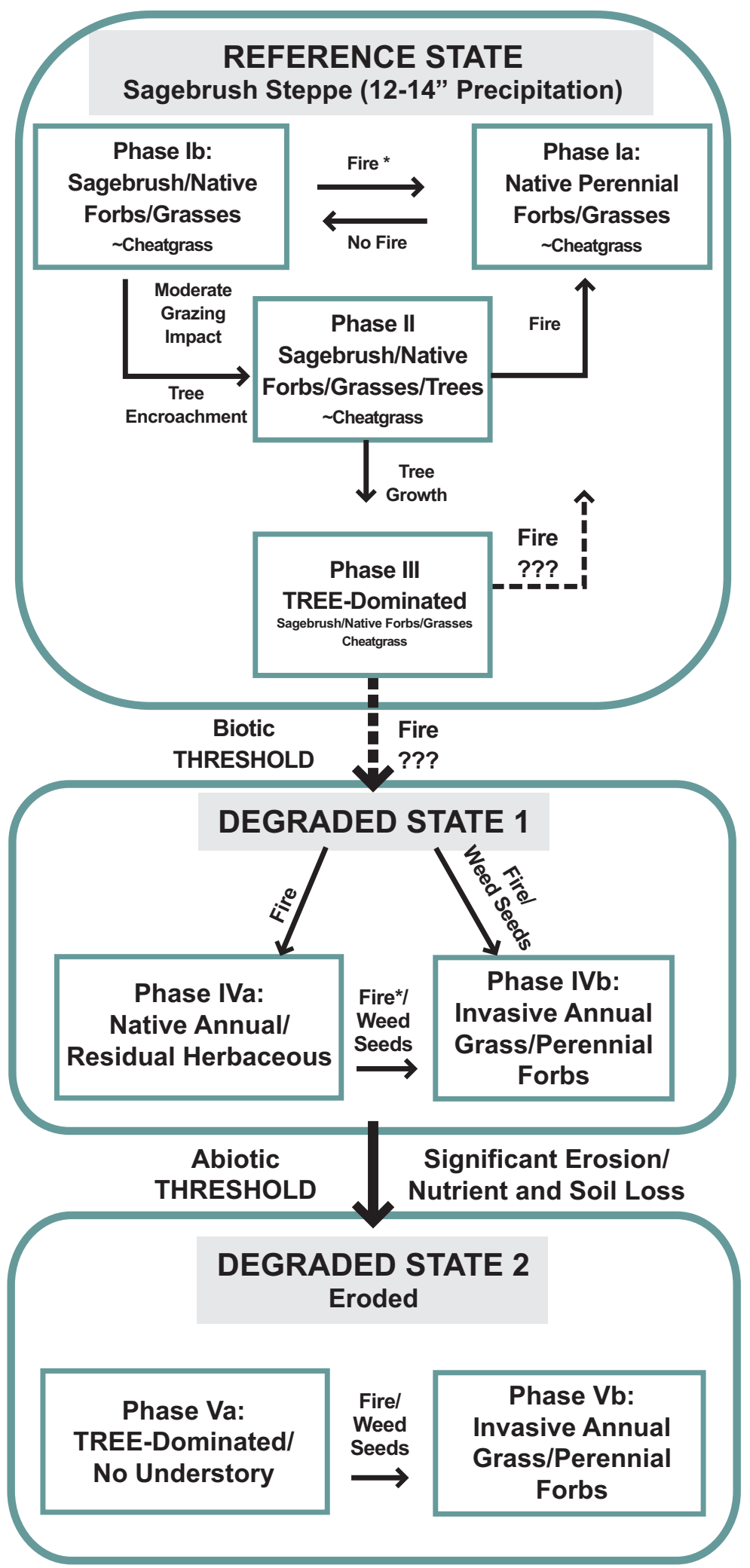

Figure 1. State-and-transition model for the woodland system (12- to 14-inch precipitation zone) focusing on vegetation only. (See Table 1 for site differences in vegetation, soils, and other inherent site features.) Font size indicates relative dominance of vegetation life form within each phase. *Fire is assumed to be severe enough to kill most of the woody vegetation. 
(Phase II). Low to moderate grazing and fire of adequate severity to kill woody vegetation can result in a shift from Phase II back to Phase I. The successional process then repeats itself. The predominate feedback mechanism that maintains the plant community within the reference state is negative as fire returns at relatively frequent intervals due to steadily increasing fuel loads that accumulate with plant succession. As long as the understory herbaceous vegetation layer remains relatively abundant and well-distributed, fuel continuity is generally sufficient to support surface fires over a fairly wide range of weather conditions. Heavy grazing or lack of fire can result in tree dominance and depletion of both shrubs and herbaceous understory species (Phase III). Fine fuels may be insufficient for surface fire and the system may not return to more seral phases within the reference state. As a result of the changes in the plant community at this point, the system is at risk of crossing a biotic threshold to Degraded State 1 . The plant community is now either dominated by invasive annuals such as cheatgrass or is characterized by the expansion of native annual cover. The threshold is "triggered" by tree competition or overgrazing, both of which are processes that decrease the ecological role of the herbaceous understory. This biotic threshold is characterized by the dominance of a positive feedback mechanism by which continued tree growth makes the system more impervious to surface fire. Even if the trees are removed, the residual plant community may be so depleted that it will not return to the reference state without re-seeding. Phase III will persist indefinitely with trees gradually acquiring more of the available resources until canopy structure, fuel loads, and weather conditions are conducive to a crown fire. A Phase IV plant community typically then results, dominated either by native annual grasses and forbs (Phase IVa) or by invasive plants if seeds are available (Phase IVb). Degraded State 2 may occur on steeper slopes and under certain soil conditions. To reach this state, an abiotic threshold is crossed in which erosion causes soil and nutrient loss (Phase V). The worst-case scenario is Phase $\mathrm{Vb}$, an eroded state where crown fire eventually occurs and leaves a condition in which only native or invasive species that can tolerate the altered conditions can establish and persist.

The sage/cheat experiment is focused on a sagebrush steppe reference state that occurs in the 10- to 12-inch precipitation zone, an ecological site in which trees almost never establish and persist. This reference state has the same two phases (Ia and Ib) as the woodland model (Figure 2). However, instead of tree expansion, both phases (particularly Phase Ib) are vulnerable to cheatgrass invasion. If grazing is absent or at low levels, native herbaceous vegetation typically remains dominant in the system even though cheatgrass becomes part of the plant community. With moderate grazing, both phases (particularly Phase $\mathrm{Ib}$ ) experience a decline in the preferred perennial grasses. In Phase II, fire kills most shrub species, and the community returns to Phase Ia. As long as native herbaceous perennials remain sufficiently abundant, periodic fire acts as a negative feedback mechanism that maintains the reference state and a plant community dominated by native perennial species. However, with heavy grazing the community transitions to Phase III, in which perennial herbaceous vegetation is reduced to relatively low cover values and cheatgrass abundance increases. Introduction of stand-replacement fire can return the community to Phase Ia, but most likely will cause the community to cross a biotic threshold to a degraded state dominated by cheatgrass (Phases IV and V). Cheatgrass is highly flammable for a longer period of time during the late spring and summer than native perennials, and it typically creates a highly continuous fine fuel bed. Thus, fire operates once again as a negative feedback mechanism, this time returning the community to cheatgrass dominance with each repeated burn. Remnant perennial shrubs that cannot tolerate fire are progressively eliminated, while perennial herbaceous species exhibit reduced capacity to produce seeds and establish in the highly competitive environment. Exotic perennial invasion can result in Phase V, a plant community codominated by cheatgrass, other annual grasses, and weedy perennial forbs. Repeat fire may return the community to Phase IV or may perpetuate Phase $\mathrm{V}$, but further research is needed to determine this. Active restoration is required to return either Phase IV or V to the reference state, but even significant efforts may fail to achieve restoration success in these systems.

\section{SageSTEP DESIGN and STMs}

SageSTEP has five key features that make it ideal for testing hypotheses developed from state-and-transition theory and for applying new knowledge in a management context. SageSTEP is:

- Experimental-allows for controlled manipulation of ecological factors that are considered to be drivers in the two experimental systems;

- Long-term (10 years post-treatment)-provides sufficient ecological post-treatment time to measure and interpret ecological response; 


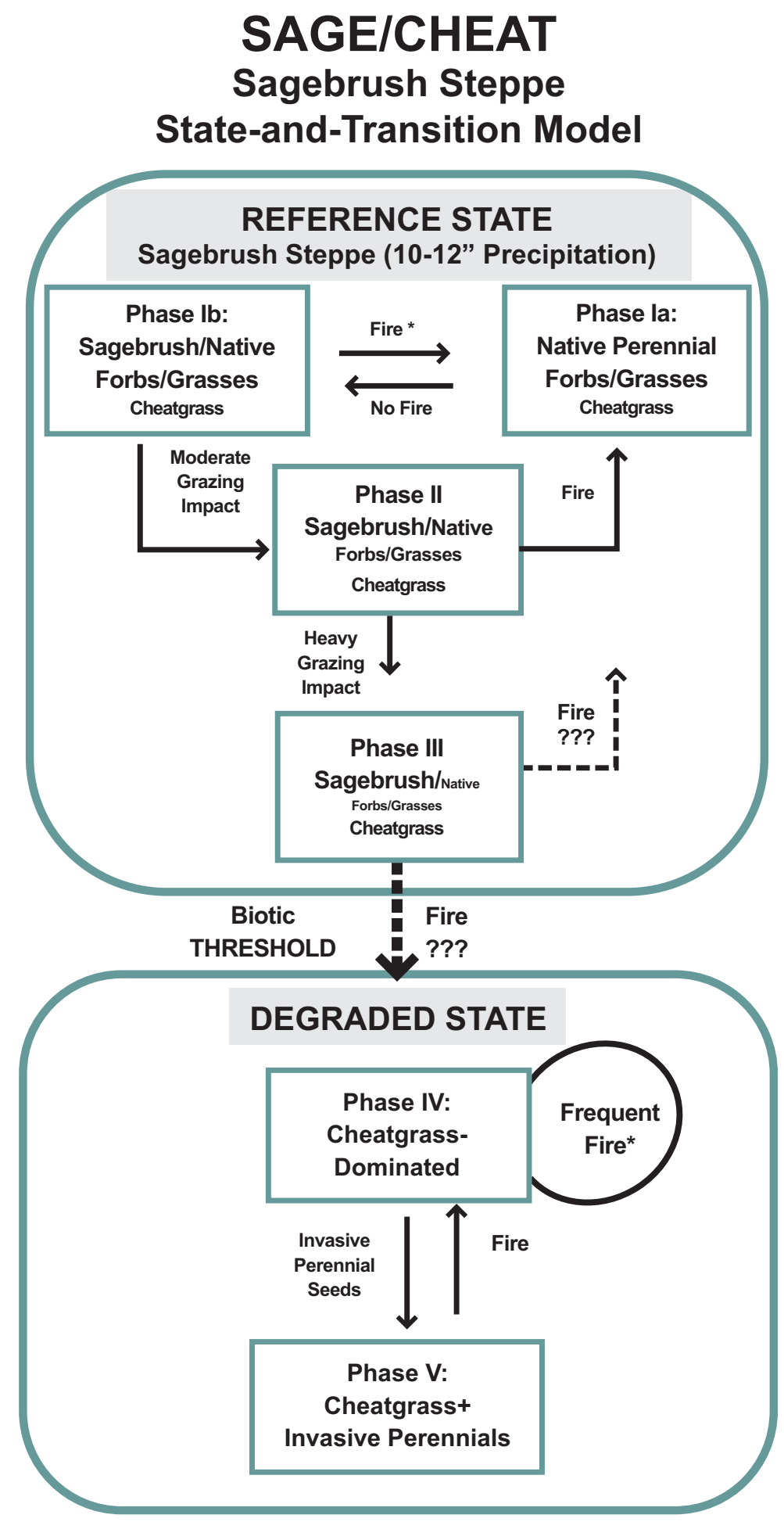

Figure 2. State-and-transition model for the sage/cheat system (10- to 12-inch precipitation zone) focusing on vegetation only. (See Table 2 for site differences in vegetation, soils, and other inherent site features.) Font size indicates relative dominance of vegetation life form within each phase. *Fire is assumed to be severe enough to kill most of the woody vegetation. 
- Multisite-evaluates responses across the range of environmental conditions that characterize the region;

- Multivariate - measures both dependent and independent variables to not only characterize response but also to identify mechanisms behind that response; and

- STM-based-applies treatments across the range of ecological conditions that characterize the states and phases within the woodland and sage/cheat STMs.

These five features are incorporated into both the woodland and sage/cheat experiments. Each experiment is comprised of several replicate sites $(\mathrm{N}=12$ for woodland; $\mathrm{N}=7$ for sage/cheat), and each site represents a block where alternative fire or fire surrogate treatments are applied at the plot level. Each treatment plot includes between 15 and 24 measurement subplots established to span a wide gradient of ecological conditions. We describe this study design in detail, starting with the treatment plot, which is designed to study treatment response across the condition gradient.

\section{Treatment Plot}

The current management focus in sagebrush steppe is to maintain or restore native sagebrush ecosystems. The dominant shrubs (Artemisia spp.) and trees are not fire-tolerant, and initial ecosystem recovery following wildfires or management treatments depends on native perennial herbaceous species that resprout or reestablish following fire and that decrease the susceptibility of these ecosystems to cheatgrass invasion (Chambers and others 2007). Total or partial removal of trees and shrubs through fire or one of its surrogates and removal of cheatgrass by applying herbicides can result in competitive release of perennial herbaceous species. Thus, vegetation recovery may depend on the relative abundance of native perennial herbaceous species and trees, shrubs, and cheatgrass in woodland and sage/cheat ecosystems and on their responses to the different treatments. SageSTEP is designed to examine vegetation response to specific treatments over these abundance gradients in woodland and sage/cheat ecosystems. Sub-plots are positioned and sized (relatively large) to capture the range of vegetation conditions within a plot. For example, the Greenville Bench control plot (woodland experiment) has an area of 25 ha ( 1250 by $200 \mathrm{~m}$ ), and the differences in tree abundance can easily be seen on the National Agriculture Imagery Program image (Figure 3a). Because tree cover is the primary driver behind declines in understory cover
(Figure 3b), an opposing response curve for understory vegetation is evident in each treatment plot. Recovery potential can be assessed with this design by applying the selected treatments across the entire plot, measuring vegetation response within the sub-plots, and then interpreting the response within the context of the vegetation gradient. If a threshold exists in herbaceous vegetation cover, below which recovery does not occur without further intervention, it likely will be identified with this design. After examination of many landscapes prior to site selection, we found that typically at least 15-ha treatment plots were necessary to capture a meaningful gradient for stands encroached by woodland species, and at least 30-ha plots were necessary for the more xeric stands in the sage/cheat experiment.

\section{Site Distribution}

While treatment of a single large plot can identify thresholds for that particular place at that particular time, managers need to know if application of the same treatment elsewhere will produce similar results. The issues of site-specific responses to treatments and variation in the position of the biotic threshold (and other STM characteristics) were addressed by conducting the same experiment across a wide range of environmental conditions. The two experiments in SageSTEP's core study are applied at 19 sites located across much of the land area occupied by sagebrush steppe vegetation in the western United States (Figure 4). All sites fall within the same Major Land Resource Area (i.e., lands that have similar vegetation and land use patterns (Bestelmeyer and others 2009). Each of these 19 sites received the full suite of treatments. Although all sites are classified as Cool Desert, weather patterns differ markedly across this geographic range. Sites in California, Oregon, Washington, and southwest Idaho have a Pacific Maritime climate, with nearly all precipitation originating in the Pacific Ocean and falling between November and June. The majority of the western juniper ecosystem lies north of the polar front gradient where temperatures are cooler, summer precipitation is decreased, and winter precipitation is increased (Mitchell 1976). In contrast, sites in Nevada and Utah have a more Continental climate, with less precipitation falling from November to June, and relatively more summer rains originating from the Gulf of Mexico, usually in July and August. Since weather systems in the Pacific and in the Gulf are somewhat independent, we expect different patterns of inter-annual weather variation across the SageSTEP network, and we expect that this variation may affect recovery after 

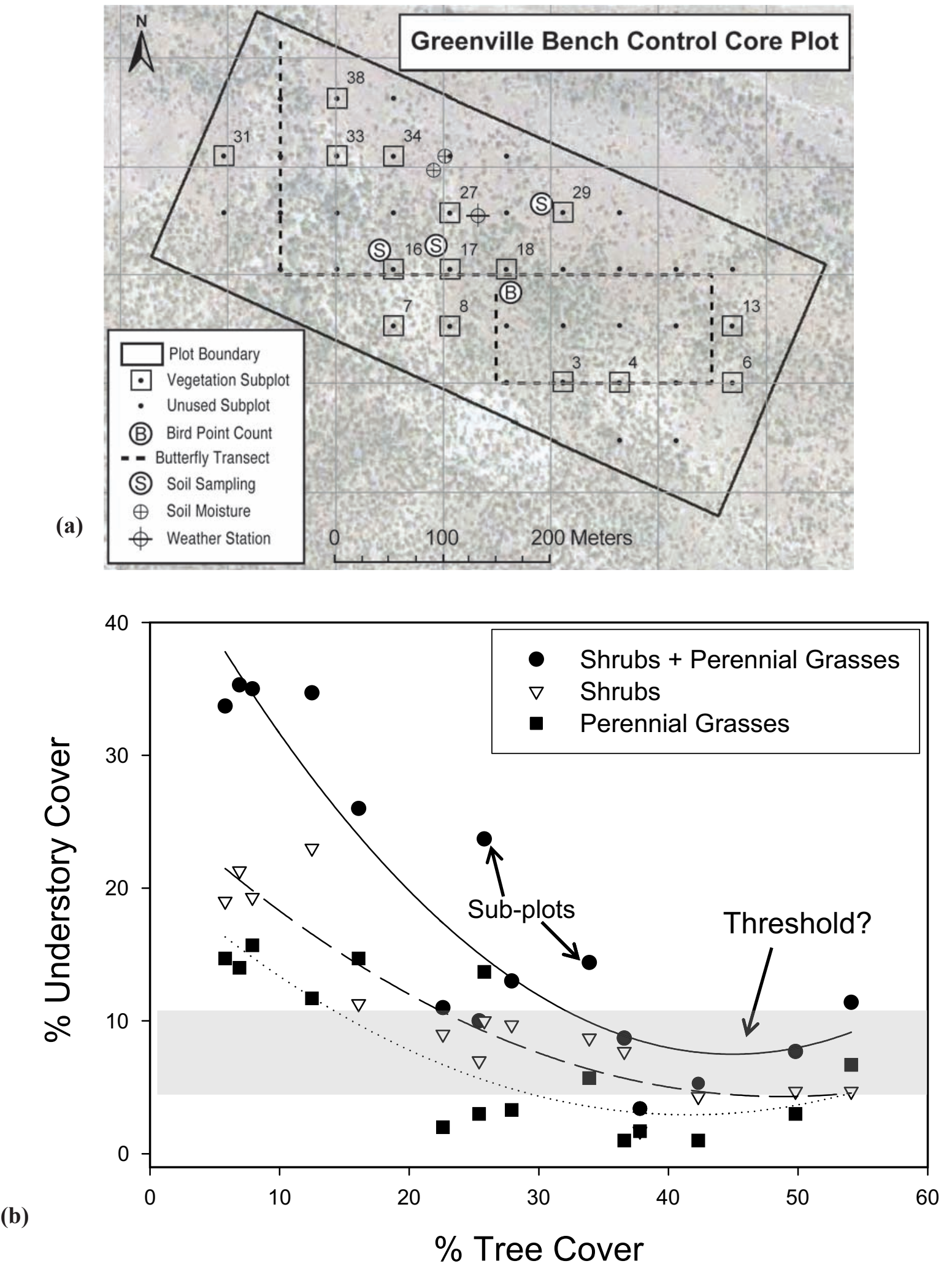

Figure 3. Greenville Bench control plot. (a) Map of plot showing location of measurement sub-plots, weather station, soil moisture stations, soil cores, bird point counts, and butterfly transects. (b) Relationship between tree cover and understory cover over the plot's condition gradient. 

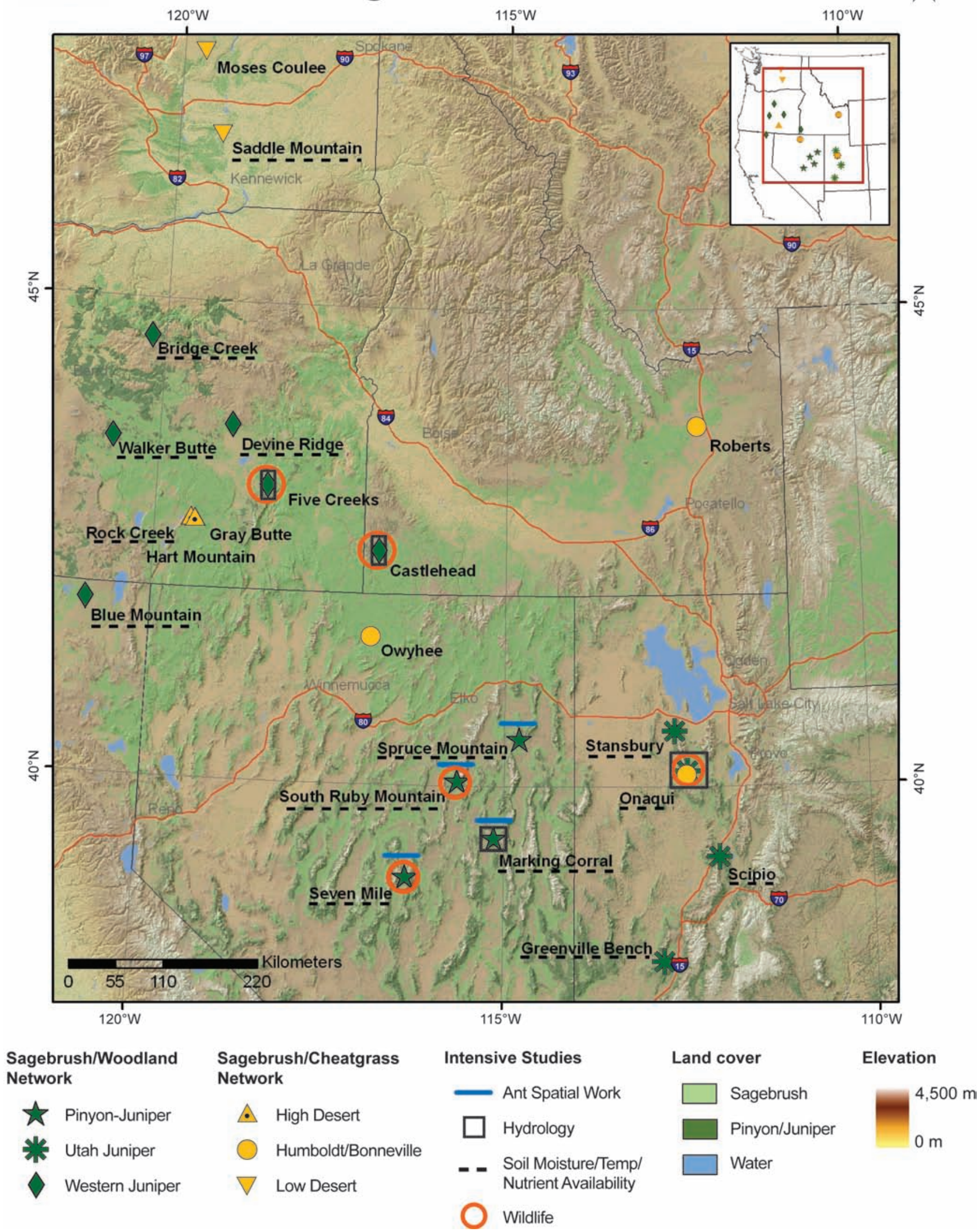

Figure 4. Map of SageSTEP Network of 21 sagebrush steppe sites, 19 of which are used in the core experiment focused on vegetation responses, and two of which are only used for wildlife (5-Creeks) or hydrology (Castlehead) research. 
treatment. If among-site recovery rates and/or patterns mirror vulnerability, then more xeric sites, or sites with higher inter-annual variation in weather, may be slower to recover relative to more mesic, or less variable, sites (Chambers and others 2007). We collect weather data at each site throughout the study period from weather stations located in the control plot of each site (Figure 3a). These data are used as a covariate in the analyses to help explain vegetation response.

The 12 woodland sites can be organized into three regions, each reflecting the dominant tree species (Figure 4). With four sites located in Oregon and Northern California, the Western Juniper Region is roughly defined by a triangle $300 \mathrm{~km}$ on the side. The four sites within the Pinyon-Juniper Region are more tightly clustered in east-central Nevada. The Utah Juniper Region consists of four sites in western Utah, spanning a north to south geographic range of roughly $400 \mathrm{~km}$. Altogether, the 12 woodland sites span a geographic range of more than $800 \mathrm{~km}$, from Bridge Creek in the northwest to Greenville Bench in the southeast, and represent conditions that vary considerably in elevation, topography, soils, current vegetation, and climate (Table 1).

The cheatgrass experiment consists of seven sites, all within the sagebrush biome but separated by more than $1000 \mathrm{~km}$ from south-central Washington to west-central Utah (Figure 4). Four of these sites are located in the western part of the sagebrush range, two are in central Oregon (High Desert Region), and two are in the Columbia Basin of southern Washington (Low Desert Region). Three of the sites are located in the eastern portion of the range (Bonneville Region), with one in Utah, one in eastern Idaho, and one in northern Nevada. Although all seven sites are typical sagebrush steppe systems, they also encompass a range of soil types, plant communities, and weather patterns (Table 2).

While most sampling occurs within the plots and sub-plots, analyses are conducted not only at the plot level, but at the site, region, and network levels. The hierarchical organization of the study reflects the sampling orientation and sets the stage for different kinds of analyses. If native perennial herbaceous vegetation has an effect on recovery and thresholds as originally predicted, we will be able to determine its relative importance at both site and regional levels for the woodland and sage/cheat experiments. Because other factors like soil characteristics, weather patterns, and abundance of other plant life forms, especially cheatgrass, likely have additional effects, we also will be able to determine their relative contribution to recovery and thresholds.

\section{Treatments}

For both the woodland and sage/cheat core experiments, a full set of treatments were applied at each site to achieve a statistical block. These treatments are commonly used to decrease woody fuels and to maintain or restore sagebrush ecosystems. The woodland experiment features three plot-level treatments: prescribed fire, cut and fell, and mastication. Treatment plots range in size from 10 to 30 ha, each of which has 15 measured sub-plots positioned to cover a broad condition gradient. Prescribed fire was applied first, between August and November of 2006, 2007, or 2008 (Table 1). The goal was to accomplish 100 percent tree mortality within each treatment plot. However, due to considerable variation in weather conditions, prescribed fires only burned between 20 and 95 percent area. For those plots in which percent area burned was low, we blackened every sub-plot where the low measurements were taken. Cut and fell and mastication treatments were implemented within six months of fire treatments. All trees $>2 \mathrm{~m}$ tall were cut down and left on the ground across the contour. An additional treatment was applied at the four Utah juniper sitesall trees $>2 \mathrm{~m}$ tall were masticated with the Bullhog ${ }^{\circledR}$, a machine with a rotary mower capable of shredding even the largest juniper trees. An untreated plot serves as a control to complete the three-treatment ensemble for each woodland site (four treatments for the Utah juniper region).

The sage/cheat experiment includes four plot-level treatments per site: prescribed fire, application of the herbicide tebuthiuron, rotary mowing, and application of the herbicide imazapic nested within each of the other treatments. Treatment plots range in size from 20 to 80 ha, each of which has 18 measured sub-plots positioned to cover a broad condition gradient. Prescribed fire was applied first, from May to October of 2006, 2007, or 2008 (Table 2). The goal was to accomplish 100 percent fire coverage. In some cases, weather conditions did not cooperate, with the result that some plots were not completely burned. In these cases, fire crews blackened every sub-plot where measurements occurred. Once fire was implemented for each site, both herbicide and mowing treatments were applied to two other plots within the following eight months. Both treatments were designed to remove about 50 percent of sagebrush cover to reduce woody fuels and release the understory herbaceous species. The herbicide tebuthiuron (N -[5-1,1-dimethylethyl-1,3,4-thiadiazol2-yl]- N,N'-dimethylurea) was applied over the entire 
plot at a rate dictated by prior testing to remove 50 percent of the overstory. Rotary mowers were set at a pre-determined height to remove 50 percent of sagebrush biomass over the entire plot. An untreated plot served as the control to complete the four-treatment ensemble of plot-level applications for each site. The pre-emergent herbicide imazapic (3-Pyridinecarboxylic acid, 2-(4,5-dihydo-4-methyl-4-(1-methylethyl)-5oxo-1H-imidazol-2-yl)-5-methyl-monoammonium salt) was applied to half of the sub-plots within each of the three or four plots per site (including control) simultaneous to each of the other treatments. At low rates, imazapic selectively acts on annual plants.

\section{Measured Variables}

SageSTEP measures well over 100 distinct variables that can be roughly classified as response (dependent) or explanatory (independent) variables. To evaluate ecological response, a comprehensive set of variables are measured within each of the 1050 sub-plots, capturing both structural and compositional elements of the system. These variables are measured pre-treatment and for at least 10 years post-treatment within each of the 0.1 -ha sub-plots ( 30 by $33 \mathrm{~m}$ ) in the two experiments. Cover and density of trees, shrubs, forbs, and grasses are measured, and analyses focus on how these vegetation components respond to treatment in relation to the vegetation gradients. Biological crust cover, bare ground cover, harvester ant mounds, and ant community structures are also measured within each sub-plot because of their potential relevance to vegetation recovery. A number of critical explanatory variables are measured to aid in interpretation of vegetation response, including: (1) inherent features of the sub-plot, such as slope, aspect, topographic position, and elevation; (2) all components of the fuel bed within sub-plots, such as standing and down woody fuel, litter, duff, and live fuels; (3) inherent soil properties, such as depth, texture, and moisture; (4) soil chemistry, with a focus on nitrogen availability and carbon; and (5) air temperature and precipitation, at weather stations placed in the center of each control plot. Each time a sub-plot is measured, two photo points are taken at the 0 - and $30-\mathrm{m}$ marks of the central $(15 \mathrm{~m})$ transect using a digital camera. These geo-referenced photo points are used to document vegetation recovery over the long term and to aid in interpretation of vegetation response. This suite of variables will aid in quantifying STM differences among sites because recovery processes likely will largely depend on how different variables interact in the context of climate zones and weather patterns. Including variables that managers or scientists believe are potentially relevant maximizes the likelihood of capturing indicator patterns that are connected to critical processes (Pyke and others 2002). Finally, it is imperative that variables be measured for at least 10 years post-treatment because of uncertainty about the length of time required for vegetation recovery and because of the community's potential to return to the reference state. In fact, time frames must be fully understood in order to complete an STM (Bestelmeyer and others 2004).

Faunal response was also measured at the treatment plot level, particularly passerine bird and butterfly response. Passerine bird point counts are conducted annually in each treatment plot for the woodland experiment only, while 1000-m butterfly transect surveys are conducted within treatment plots for both the woodland and sage/cheat experiments. Thus, the effects of fire and fire surrogates on both passerine bird and butterfly abundances can be assessed with this design. Because average home range size for passerine birds is too large to study populations within typical SageSTEP treatment plots, bird research also includes intensive demographic work on seven species of sageobligate passerine birds within 10 400-ha plots-one control and one prescribed burn plot for each of five woodland sites (Figure 4). Because sage-obligate passerines are known to have similar habitat preferences to sage grouse (a species of concern), research on these birds should provide insight into treatment effects on grouse populations. More generally, an important rationale for measuring faunal response to treatment is to understand the extent to which other components of the system not directly related to vegetation management track the response of vegetation over time. Understanding faunal effects will provide managers with more confidence on how their treatments influence the whole system. SageSTEP can identify inconsistencies in treatment response between the flora and fauna and potential time lags in faunal response as key components of habitat recovery after treatment. SageSTEP biodiversity research will help patch the schism that has developed in recent years between rangeland professionals focused exclusively on vegetation and production and those more interested in the health of whole ecosystems, which is commonly expressed as various measures of biodiversity (Bestelmeyer 2006).

Finally, the extent to which woodland encroachment affects water relations has been a significant concern in recent years among managers of the sagebrush biome. Variations in site infiltration, runoff, 
and erosion are closely correlated with variations in vegetation and surface soil conditions (Pierson and others 2002; Rau and others 2005). In particular, pinyon and juniper trees are highly competitive for soil water, and tree dominance typically results in major declines in understory vegetation (Figure $3 b$ ). Under these conditions, undesirable hydrological conditions can develop on steep slopes, causing increased erosion and sediment transport (Degraded State 2; Figure 1). SageSTEP hydrology research focuses on the conditions under which the most deleterious effects occur to determine if critical thresholds exist in vegetation and ground cover that significantly influence hillslope erosion and if management treatments influence these thresholds.

\section{Analyses}

Both univariate and multivariate analyses are being used for the two ecological experiments. For univariate analyses, we will use PROC GLIMMIX (SAS Institute Inc. 2004), with replication provided at the site level for both woodland $(\mathrm{n}=12)$ and sage/cheat $(\mathrm{n}=7)$ experiments. This ensures a statistically valid design for the overall experiment in which differences among sites, treatments, and treatment years can be tested for the suite of ecological variables examined. Variables believed to be influencing ecosystem trajectories, like tree cover, cheatgrass biomass, or soil texture, will be treated as covariates to examine their overall influence on other response variables. To capture whole system responses to fire and fire surrogate treatments, we will use multivariate methods. Information on whole system response is valuable to managers because it allows them to evaluate treatment tradeoffs for key variables. Multivariate methods such as ordination and classification are best used for investigations on how plant and animal communities vary along spatial gradients and how they respond to treatments (McCune and Grace 2002).

To evaluate how relationships among components within a system respond to treatment, we will use structural equation modeling (SEM) (Grace 2006). This analysis tool requires that the investigator build hypothetical models from prior knowledge that include the key variables and their causal relationships not only to the dependent variable but to one another, and then test the models with data from the experiment. For example, we can examine how soil type influences the degree to which fire and fire surrogates affect plant species diversity. Factors such as slope, elevation, aspect, and initial fuel loads can also be evaluated in the context of a structural equation model. In summary, analytical results are used not only to identify significant differences in responses among sites, but also to provide confidence intervals for the more detailed STMs that will emerge from the study.

\section{Human Aspects}

SageSTEP is largely a comprehensive field study focused on ecological aspects of woodland expansion and cheatgrass invasion on sagebrush steppe lands of the Interior West. However, to improve public understanding of invasion and recovery processes in sagebrush steppe and to gain acceptance of applying recommended treatments, certain socioeconomic aspects need to be addressed. For instance, treatments will not be applied if the public doesn't accept them or if they are too costly relative to other land management options. Further, research results must be communicated to key stakeholders in order for the results' full potential to be realized. In this section, we briefly outline activities underway to assess sociopolitical, economic, and outreach aspects of SageSTEP.

\section{Sociopolitical}

Each management treatment evaluated in this project is a potentially controversial practice that might meet resistance from citizens and/or managers when applied to public lands. Because National Environmental Policy Act (NEPA) prescribes that Federal land managers must closely involve the public whenever treatment decisions are made, it is important to understand how treatments are perceived and accepted by various sectors of the public.

The sociopolitical component of SageSTEP assesses the social and political feasibility of alternative treatments, with feasibility defined as a function of positive or negative perceptions of the general public, interest group members, and land managers. Our intent is to identify factors in the treatments, or the conditions those treatments produce, that constrain or facilitate implementation of practices. Also included in those factors is the current state of ecological systems relative to ecological thresholds. While the research questions focus on the practical issue of choosing among potential restoration actions, the study also explores more basic questions about decisionmaking with uncertainty and about using the foundations of social acceptability (Shindler and others 2002) as guiding principles of contemporary land management. 


\section{Economic}

The goal of SageSTEP economics work is to provide a comprehensive understanding of the tradeoffs and incentives that face decisionmakers at various levels when they consider whether to treat sagebrush steppe lands. The economic research consists of four parts:

1. A dynamic bioeconomic model that combines features of a state-and-transition ecological model with fire, invasives, and economic decision variables (treatment and grazing levels) to predict how system resilience changes with management decision variables

2. A ranch-level model to predict ranchers' incentives in decisions regarding treatment options

3. A model to predict county-level impacts on employment and income by sector associated with alternative landscape characteristics caused by treatment or lack of treatment

4. A valuation of expected changes in flows of nonpriced goods and services brought about by decisions to treat sagebrush steppe lands that have been degraded by cheatgrass invasion or woodland encroachment

\section{Outreach}

Although SageSTEP will generate information for a wide variety of people, its principal outputs will consist of applied ecological and socioeconomic information designed to be useful to land managers. A Communication Plan has been developed that can adapt to the needs of practitioners and the public. The purpose of the Communication Plan is to guide the project through the outreach process by providing both conceptual and process frameworks at the network and site levels. Principal products and activities include:

- A Web site that is designed and maintained by a dedicated outreach coordinator

- A newsletter produced three times per year that informs stakeholders on the progress of SageSTEP

- Annual workshops for managers to maintain clear lines of communication

- Field tours for a variety of audiences

- Presentations at scientific and management-oriented meetings

- Scientific publications in which primary findings are published
- Other outreach materials that are developed as opportunities arise in order to serve a variety of audiences, including general or specific publics and land managers

- A set of three User's Guides to be used by managers in the field

The User's Guides exemplify the approach we have chosen: to deliver scientific information to managers' hands. Each User's Guide is focused on a Land Resource Unit with similar characteristics and issues to the perspective of the land manager (e.g., Western Juniper, Pinyon-Juniper, Wyoming Big Sagebrush). Each is grounded in scientific literature and provides a list of key publications that support its perspective and can be cited in NEPA documents. Each leads the user through a series of questions designed to help the manager make decisions on a particular stand or watershed. We anticipate that results from both experiments will be used to update and expand Ecological Site Descriptions for each of the distinct sites within the SageSTEP network and will update each of the three User's Guides. Finally, the effectiveness of the outreach program will be evaluated regularly with surveys taken at the annual manager workshops.

\section{Summary}

As a single study focused on sagebrush steppe ecosystems of the Interior West, SageSTEP has several features that make it unique as a research project that tests hypotheses associated with state-and-transition theory. SageSTEP is: (1) Experimental-allows for controlled manipulation of ecological factors that are considered to be drivers in the woodland and sage/ cheat experimental systems; (2) Long-term (10 years post-treatment) - provides sufficient ecological posttreatment time to measure and interpret ecological response; (3) Multisite - evaluates responses across the range of environmental conditions that characterize the region; (4) Multivariate - measures both dependent and independent variables, not only to evaluate response but to identify mechanisms behind that response; and (5) STM-based - applies treatments across the range of ecological conditions that characterize the states and phases within the woodland and sage/cheat STMs. Information from SageSTEP will improve existing Ecological Site Descriptions, including details on among-site soil variation, vegetation, threshold dynamics, and the form of state-and-transition models, as they apply to both the flora and the fauna of 
sagebrush steppe systems. SageSTEP also explores human aspects of the invasion on sagebrush steppe lands, including the social acceptability of alternative treatments, the economic tradeoffs and incentives that face land managers dealing with woodland and cheatgrass invasion, and alternative methods for disseminating research results to key stakeholders.

\section{Acknowledgments}

This is Contribution Number 5 of the Sagebrush Steppe Treatment Evaluation Project (SageSTEP), funded by the U.S. Joint Fire Science Program (JFSP Grant \#05-S-08). Substantial funds are provided by the research institutions with which the principal investigators are affiliated. We are also grateful to our management partners who bore the full cost of treatment implementation: the Bureau of Land Management, Forest Service, Fish and Wildlife Service, and The Nature Conservancy. This manuscript was considerably improved by comments from Pat Kennedy (Oregon State University), David Briske (Texas A\&M), and two anonymous reviewers.

\section{References}

Bestelmeyer, B.T. 2006. Threshold concepts and their use in rangeland management and restoration: The good, the bad, and the insidious. Restoration Ecology 14:325-329.

Bestelmeyer, B.T., A.J. Tugel, G.L. Peacock Jr., D.G. Robinett, P.L. Shaver, J.R. Brown, J.E. Herrick, H. Sanchez, and K.M. Havstad. 2009. State-and-transition models for heterogeneous landscapes: A strategy for development and application. Rangeland Ecology and Management 62:1-15.

Bestelmeyer, B.T., J.E. Herrick, J.R. Brown, D.A. Trujillo, and K.M. Havstad. 2004. Land management in the American southwest: A state-and-transition approach to ecosystem complexity. Environmental Management $34: 38-51$.

Betancourt, J. L. 1987. Paleoecology of pinyon-juniper wood-lands: Summary. In: R.L. Everett, comp. Proceedings - pinyon-juniper conference. Gen. Tech. Rep. INT-GTR-215. Ogden, UT: U.S. Department of Agriculture, Forest Service, Intermountain Research Station: 129-139.

Briske, D.D., S.D. Fuhlendorf, and F.E. Smeins. 2005. Stateand-transition models, thresholds, and rangeland health: A synthesis of ecological concepts and perspectives. Rangeland Ecology and Management 58:1-10.
Briske, D.D., S.D. Fuhlendorf, and F.E. Smeins. 2006. A unified framework for assessment and application of ecological thresholds. Rangeland Ecology and Management 59:225-236.

Bunting, S.C., J.L. Kingery, M.A. Hemstrom, M.A. Shroeder, R.A. Gravermier, and W.J. Hann. 2002. Altered rangeland ecosystems in the interior Columbia Basin. Gen. Tech. Rep. PNW-GTR-553. Portland, OR: U.S. Department of Agriculture, Forest Service, Pacific Northwest Research Station. 71 p.

Chambers, J.C. 2000. Seed movements and seedling fates in disturbed sagebrush steppe ecosystems: Implications for restoration. Ecological Applications 10:1400-1413.

Chambers, J., B.A. Roundy, R.R. Blank, S.E. Meyer, and A. Whitaker. 2007. What makes Great Basin sagebrush ecosystems invasible by Bromus tectorum? Ecological Monographs 77:117-145.

Chambers, J.C., S.B. Vander Wall, and E. W. Schupp. 1999. Seed and seedling ecology of pinyon and juniper species in the pygmy woodlands of western North America. Botanical Reviews 65(1):1-38.

Dyksterhuis, E.J. 1949. Condition and management of rangeland based on quantitative ecology. Journal of Range Management 2:104-115.

Grace, J.B. 2006. Structural equation modeling and natural systems. New York: Cambridge University Press. 365 p.

Holling, C.S. 1973. Resilience and stability of ecological systems. Annual Review of Ecology and Systematics $4: 1-23$.

Knick, S.T., D.S. Dobkin, J.T. Rotenberry, M.A. Schroeder, M.W. Vander Haegen, and C. Van Riper III. 2003. Teetering on the edge or too late? Conservation and research issues for avifauna of sagebrush sagebrush habitats. Condor 105:611-634.

Laycock, W.A. 1991. Stable states and thresholds of range condition on North American rangelands: A viewpoint. Journal of Range Management 44:427-433.

McCune, B. and J. Grace. 2002. Analysis of ecological communities. Gleneden Beach, OR: MJM Software Design. 300 p.

Miller, R.F. and E.K. Heyerdahl. 2008. Fine-scale variation of historical fire regimes in semi-arid shrubland and woodland: An example from California, USA. International Journal of Wildland Fire 17:245-254.

Miller, R.F. and J.A. Rose. 1999. Fire history and western juniper encroachment in sagebrush steppe. Journal of Range Management 52:550-559.

Miller, R.F. and R.J. Tausch. 2001. The role of fire in pinyon and juniper woodlands: A descriptive analysis. In: K.E.M. Galley and T.P. Wilson, eds. Proceedings of the invasive species workshop: The role of fire in the control and spread of invasive species. Tall Timbers Research Station Miscellaneous Publication 11:15-30. 
Miller, R.F., T.J. Svejcar, and J.A. Rose. 2000. Impacts of western juniper on plant community composition and structure. Journal of Range Management 53:574-585.

Mitchell, V.L. 1976. Regionalization of climate in the western United States. Journal of Applied Meteorology 5:920-927.

Neilson, R.P., J.M. Lenihan, D. Bachelet, and R.J. Drapek. 2005. Climate change implications for sagebrush ecosystem. Transactions North American Wildlife and Natural Resources Conference 70:145-159.

Noss, R.F., E.T. LaRoe III, and J.M. Scott. 1995. Endangered ecosystems of the United States: A preliminary assessment of loss and degradation. Biological Report 28. Washington, DC: National Biological Service.

Pellant, M. 1994. History and applications of the Intermountain greenstripping program. In: Proceedingssymposium on ecology and management of annual rangelands; 1992 May 18-22; Boise, ID. Gen. Tech. Rep. INT-GTR-313. Ogden, UT: U.S. Department of Agriculture, Forest Service, Intermountain Research Station: 63-68.

Pierson, F.B., K.E. Spaeth, M.E. Weltz, and D.H. Carlson. 2002. Hydrologic response of diverse western rangelands. Journal of Range Management 55:558-570.

Pyke, D.A., J.E. Herrick, P. Shaver, and M. Pellant. 2002. Rangeland health attributes and indicators for qualitative assessment. Journal of Range Management 55:584-597.

Pyke, D.A. and S.T. Knick. 2003. Plant invaders, global change and landscape restoration. In: N. Allsopp, A.R. Palmer, S.J. Milton, K.P. Kirkman, G.I.H. Kerley, C.R. Hurt, and C.J. Brown, eds. Proceedings of the VIIth International Rangelands Congress; 2003 July 26-August 1; Durban, South Africa: 278-288.

Rau, B.M., J.C. Chambers, R.R. Blank, and W.W. Miller. 2005. Hydrologic response to prescribed fire in central Nevada pinyon-juniper (Pinus monophylla-Juniperus osteosperma) woodland. Journal of Range Management 58:614-622.

SAS Institute, Inc. 2004. SAS System for Microsoft Windows. Cary, NC: SAS Institute, Inc.
Shindler, B., M. Brunson, and G. Stankey. 2002. Social acceptability of forest conditions and management practices: A problem analysis. Gen. Tech. Rep. PNWGTR-537. Portland, OR: U.S. Department of Agriculture, Forest Service, Pacific Northwest Research Station. 68 p.

Tausch, R., C.L. Nowak, and S.A. Mensing. 2004. Climate change and associated vegetation dynamics during the Holocene: The paleoecological record. In: J.C. Chambers and J.R. Miller, eds. Great Basin riparian ecosystems: Ecology, management, and restoration. Washington, DC: Island Press: 24-48.

Tausch, R.J. and C.L. Nowak. 2000. Influences of Holocene climate and vegetation changes on present and future community dynamics. Journal of Arid Land Studies 10S:5-8.

West, N.E. and N. Van Pelt. 1987. Successional patterns in pinyon-juniper woodlands. In: R.L. Everett, comp. Proceedings - pinyon-juniper conference. Gen. Tech. Rep. INT-GTR-215. Ogden, UT: U.S. Department of Agriculture, Forest Service, Intermountain Research Station: 43-52.

Westoby, M., B. Walker, and I. Noy-Meir. 1989. Opportunistic management for rangelands not at equilibrium. Journal of Range Management 42:266-274.

Whisenant, S.G. 1990. Changing fire frequencies on Idaho's Snake River Plains: Ecological and management implications. In: E.D. McArthur, E.M. Romney, S.D. Smith, and P.T. Tueller, comps. Proceedings - symposium on cheatgrass invasion, shrub die-off, and other aspects of shrub biology and management; 1989 April 5-7; Las Vegas, NV. Gen. Tech. Rep. INT-GTR-276. Ogden, UT: U.S. Department of Agriculture, Forest Service, Intermountain Research Station: 4-10.

Wisdom, M.J., M.M. Rowland, B.C. Wales, M.A. Hemstrom, W.J. Hann, M.G. Raphael, R.S. Holthausen, R.A. Gravenmier, and T.D. Rich. 2002. Modeled effects of sagebrush-steppe restoration on Greater Sage-Grouse in the interior Columbia Basin, USA. Conservation Biology 16:1223-1231. 


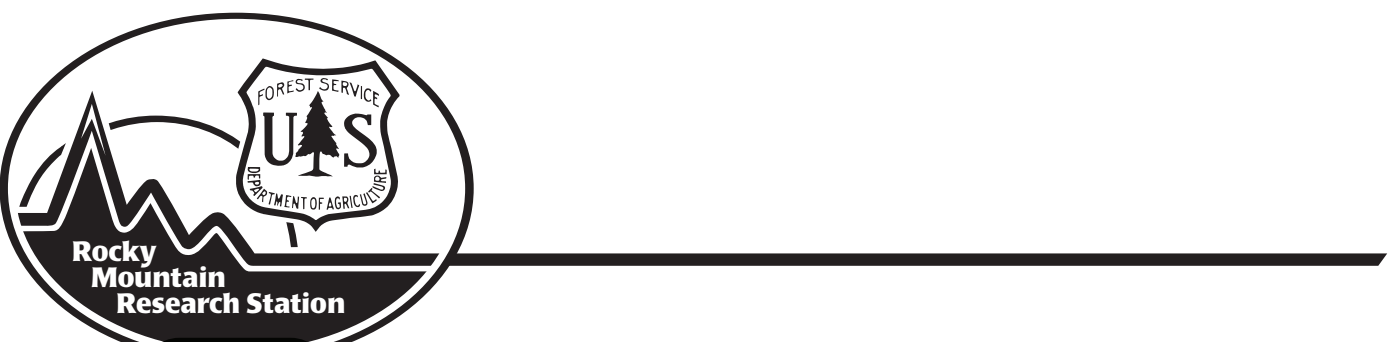

The Rocky Mountain Research Station develops scientific information and technology to improve management, protection, and use of the forests and rangelands. Research is designed to meet the needs of the National Forest managers, Federal and State agencies, public and private organizations, academic institutions, industry, and individuals. Studies accelerate solutions to problems involving ecosystems, range, forests, water, recreation, fire, resource inventory, land reclamation, community sustainability, forest engineering technology, multiple use economics, wildlife and fish habitat, and forest insects and diseases. Studies are conducted cooperatively, and applications may be found worldwide.

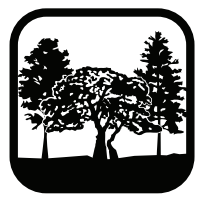

\author{
Station Headquarters \\ Rocky Mountain Research Station \\ 240 W Prospect Road \\ Fort Collins, CO 80526
}

(970) 498-1100

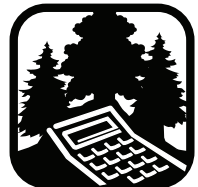

Research Locations

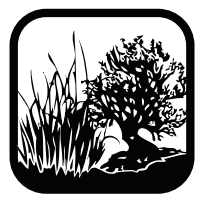

Flagstaff, Arizona

Fort Collins, Colorado

Boise, Idaho

Moscow, Idaho

Bozeman, Montana

Missoula, Montana
Reno, Nevada

Albuquerque, New Mexico

Rapid City, South Dakota

Logan, Utah

Ogden, Utah

Provo, Utah

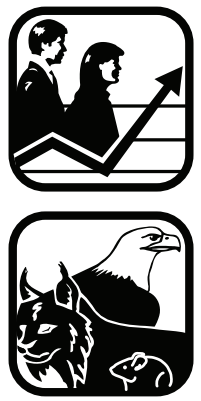

The U.S. Department of Agriculture (USDA) prohibits discrimination in all its programs and activities on the basis of race, color, national origin, age, disability, and where applicable, sex, marital status, familial status, parental status, religion, sexual orientation, genetic information, political beliefs, reprisal, or because all or part of an individual's income is derived from any public assistance program. (Not all prohibited bases apply to all programs.) Persons with disabilities who require alternative means for communication of program information (Braille, large print, audiotape, etc.) should contact USDA's TARGET Center at (202) 720-2600 (voice and TDD). To file a complaint of discrimination, write to USDA, Director, Office of Civil Rights, 1400 Independence Avenue, S.W., Washington, DC 20250-9410, or call (800) 795-3272 (voice) or (202) 720-6382 (TDD). USDA is an equal opportunity provider and employer. 